\title{
Synthesis of Silver Nanoparticles with Reductant of Java Long Pepper Leaf Extract (Piper Retrofractum Vahl) and Its Application as a Mercury Detector
}

\author{
Muhamad Allan Serunting ${ }^{*}$, Prio Santoso ${ }^{1}$, Indah Puspita Sari ${ }^{2}$, \\ Riyanto Widodo ${ }^{1}$
}

${ }^{1}$ Chemistry, Faculty of Science, Institut Teknologi Sumatera, Jl. Terusan Ryacudu, Way Huwi, Lampung Selatan, Lampung, Indonesia 35365

${ }^{2}$ Study Programme of Cosmetic Technology, Science, Institut Teknologi Sumatera, Jl. Terusan Ryacudu, Way Huwi, Lampung Selatan, Lampung, Indonesia 35365

*Corresponding author, email: muhamad.serunting@ki.itera.ac.id

(c) (1) (2)

\begin{abstract}
The synthesis of silver nanoparticles using the green chemistry concept utilizing Java long pepper leaf extract as a reducing agent has been successful. Silver nanoparticles were synthesized under optimum 1 $\mathrm{mM}$ silver nitrate concentration, $250 \mu \mathrm{L}$ Java long pepper leaf extract, and 30 minutes under sunlight radiation. The silver nanoparticles formed can be confirmed by the change in the color of the solution from colorless to brownish red, indicating a reduction of $\mathrm{Ag}^{+}$to $\mathrm{Ag}^{\mathrm{o}}$. The Uv-vis spectrum showed a peak Surface Plasmon Resonance (SPR) at $441 \mathrm{~nm}$. The FTIR spectrum showed that functional groups' vibrations in the Java Long PepperLeaf extract confirm that the phenol, alkaloid, and flavonoid compounds present in the extract act as reducing agents. TEM images show spherical silver nanoparticles with an average diameter of $17.65 \mathrm{~nm}$. The potential of silver nanoparticles to detect $\mathrm{Hg}$ (II) metal is evidenced by a decrease in the color intensity of the silver nanoparticle solution along with the increasing concentration of $\mathrm{Hg}(\mathrm{II})$, which reacts back-oxidizing $\mathrm{Ag}^{\mathrm{o}}$ to $\mathrm{Ag}^{+}$. The value of the correlation coefficient of the linear equation is 0.9807 .
\end{abstract}

Keywords: silver nanoparticles, green synthesis, mercury detection

\section{Introduction}

Silver nanoparticles are collections of silver atoms with sizes between 1-100 $\mathrm{nm}$. Nanoparticles are currently attracting the attention of scientists because of their unique electrical, biological and optical properties. Silver nanoparticles are known to have antimicrobial properties, so that silver nanoparticles are one of the components added to wound dressings, antiseptics, and antimicrobial coatings on medical devices. (Phongtongpasuk et al., 2016).

Synthesis of silver nanoparticles is generally carried out through the method of thermal decomposition of silver compounds (Nakano et al., 2016), electrochemistry (Starowicz et al., 2006), microwave (Parveen et al., 2016). This method is economically quite expensive because it requires high energy, uses hazardous chemical compounds, and produces toxic waste to humans. This is not following the principles of Green Chemistry, one of which aims to design chemical synthesis products by minimizing toxic waste byproducts. An alternative developed for the synthesis of silver nanoparticles in green synthesis without using toxic chemical compounds is a biosynthetic method using extracts 
from plants as stabilizers and reducing agents. Biosynthesis of silver nanoparticles using plant extracts has several advantages: relatively cheap, easy processing, and easy refining process, and the process is classified as green synthesis.

Researchers have used extracts of various kinds of plants as reducing agents to synthesize silver nanoparticles. Among them are using dragon fruit skin (Phongtongpasuk et al., 2016), pomegranate skin (Shanmugavadivu et al., 2014), pumpkin (Iyer and Panda, 2018), etc. Java Long Pepper (Piper retrofractum Vahl) is a native Indonesian plant that is useful as a medicinal herb and spices. The chemical compounds contained in Java Long Pepper are alkaloids such as sylvatine, piperine, piperlonguminine, piperlongumine, filfiline, guineensine, sitosterol, and methyl piperate and essential oils. The piperine content in the fruit in Java Long Pepperes ranges from 4-6\%, while the essential oil is around $0.9 \%$ (Mujahid et al., 2018)

Mercury has a density of $13,546 \mathrm{gm} / \mathrm{cm}^{3}$, so it is classified as a heavy metal group. Mercury is a metal that is toxic to human health when exposed directly to or enters the human body through environmental pollution. The metal mercury $\mathrm{Hg}^{2+}$ ions are the most stable and widespread mercury contaminants. Based on the government regulation, mercury's permissible threshold level should not be more than $0.001 \mathrm{ppm}$ in drinking water. The importance of clean water for human survival has made researchers focus on detecting mercury levels in the water. Pollution due to the release of heavy metals into the aquatic environment is significant to study because the presence of heavy metals in the aquatic environment will make these metals accumulate in the body of marine life so that if human consumption will cause poisoning and even death (Khusnia et al., 2019).

Some of the methods commonly used to detect the presence of mercury with accuracy and precision are atomic absorption spectrometry (AAS) (Bulska et al., 1995), electrochemical analysis (Martín-Yerga et al., 2013), inductively coupled plasma mass spectrometry (ICP-MS) (Ho Lee et al., 2019), and cold vapor atomic fluorescence spectrometry (Cava-Montesinos et al., 2004). However, this method requires expensive equipment, expensive maintenance, complex sample preparation and is not easy to apply in the field's analytical applications. In recent years gold and silver nanoparticles have been widely used in the colorimetric analysis for the sensor of chemical compounds, biosensors of various substances (such as viruses, cancer cells, toxic substances, pesticides, heavy metals, and inorganic and organic pollutants in water) (Maiti et al., 2016). In this study, the researchers explored the use of Java Long Pepper (Piper retrofractum Vahl) leaf extract as a reducing agent in the synthesis process of silver nanoparticles and have the potential to detect mercury metal ions in water.

\section{Material and Method \\ 2.1 Material}

The material used in this research process is silver nitrate $\left(\mathrm{AgNO}_{3}\right)$, Java Long Pepper leaf waste, $\mathrm{HCl}$. $\mathrm{NaOH}, \mathrm{HgCl}_{2}$, Whatman filter paper, and distilled water. The equipment used was a micropipette and a tip with a size of 100-100o $\mu \mathrm{L}$ (Eppendrof, Germany); the Genesys 150 Spectrophotometer (Thermo Scientific) was used to measure the absorbance of the maximum peak absorption area of silver nanoparticles. Characterization of the specific functional groups' determination in the sample using the Fourier Transform Infrared (FTIR) instrument (Agilent Cary 630). Transmission Electron Microscopy (TEM) (Hitachi H-710o).

\subsection{Java Long Pepper Preparation}

Fresh Java Long Pepper leaves are washed with water to remove stuck dirt, cut into small pieces. Ten grams of chili leaves boil in $100 \mathrm{~mL}$ of distilled water for 15 minutes at $80^{\circ} \mathrm{C}$ to obtain a more large extract. The extract is then filtered through Whatman paper No.1. The resulting extract is stored in a refrigerator at four ${ }^{\circ} \mathrm{C}$ for use in the silver nanoparticle synthesis. 


\subsection{Synthesis of silver nanoparticles}

A total of $20 \mathrm{~mL}$ of silver nitrate solution with various concentrations of $0.1 ; 0.5 ; 1$ and $2 \mathrm{mM}$ were prepared in glass bottles and added dropwise with a solution of Java Long Pepper leaf extract (Piper retrofractum Vahl) with volume variations of 100, 250, 500, 1000 and $2000 \mu \mathrm{L}$. Then let stand for a variation of time 5, 15, 30, and 60 minutes in the sun. Various volume comparisons of the extract and silver nitrate were made to determine the optimum conditions for the ratio of the formation of silver nanoparticles. The synthesized solution was measured using a Uv-Vis spectrophotometer to see the maximum absorption, which indicates that nanoparticles have been formed.

\subsection{Detection of mercury ions in water}

The 1000 ppm $\mathrm{Hg}$ (II) stock solution was prepared by dissolving 0.13534 grams of $\mathrm{HgCl}_{\neg 2}$ into a $100 \mathrm{~mL}$ measuring flask using distilled water. Then, the $\mathrm{Hg}(\mathrm{II})$ concentration solution's variation is prepared from the dilution of the stock that has been made. Furthermore, $10 \mathrm{~mL}$ of silver nanoparticle solution was prepared in 5 vials; each vial was added with $10 \mathrm{~mL}$ of $\mathrm{Hg}(\mathrm{II})$ solution with various 10, 20, 40 , and $80 \mathrm{ppm}$ concentrations. The absorbance of the solution color change was measured using the UV-Visible Spectrophotometer instrument.

\section{Result and Discussion}

\subsection{Nanoparticles Synthesis}

A total of $20 \mathrm{~mL}$ of silver nitrate solution with a concentration of $1 \mathrm{mM}$ was prepared in 4 glass bottles and added dropwise with a Java Long Pepper leaf extract (Piper retrofractum Vahl) with volume variations of $100,250,500,1000$ and $2000 \mu \mathrm{L}$. Let stand for 15 minutes in the sun. The silver nitrate solution changes color from clear to brownish red. This occurs due to the reduction of $\mathrm{Ag}^{+}$ions to $\mathrm{Ag}^{\mathrm{o}}$ (silver nanoparticles) (Rafique et al., 2017). Synthesis utilizes sunlight to accelerate the reduction reaction rate of the formation of silver nanoparticles. This is in line with the green chemistry concept (Shahriari et al., 2019). The silver nanoparticle synthesis scheme and its potential to detect mercury metal can be seen in Figure 1.

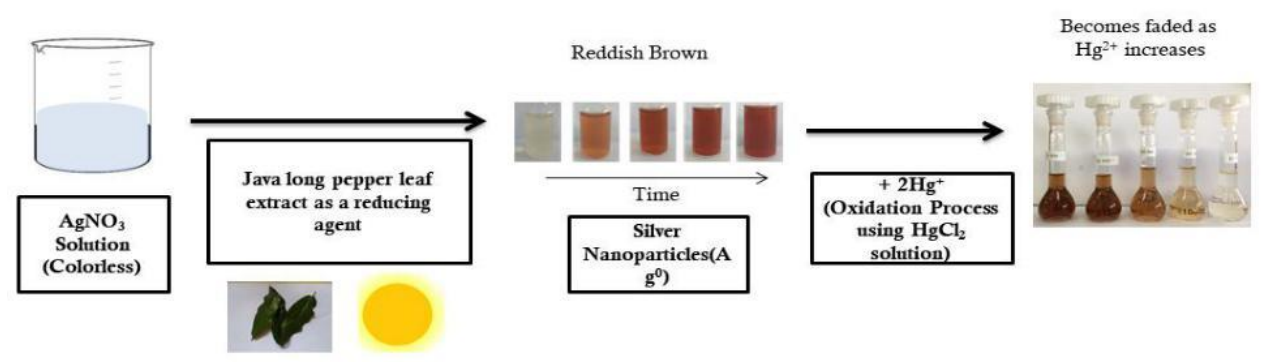

Figure 1. Schematic of silver nanoparticle synthesis and its potential to detect mercury metal

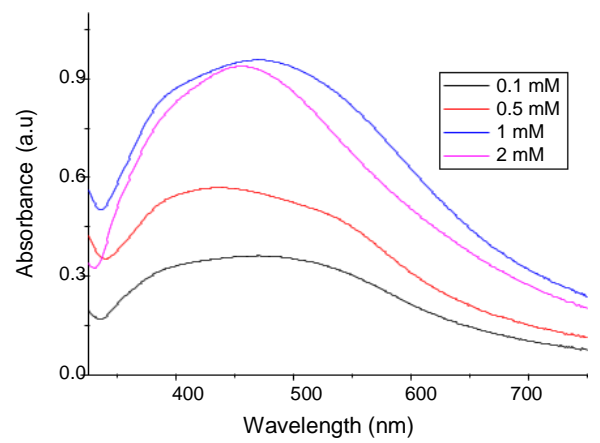

Figure 2. Effect of silver nitrate solution concentration on the synthesis of silver nanoparticles. 
Figure 2 shows the effect of silver nitrate precursor solution concentration on the synthesis of silver nanoparticles. It can be seen that the silver nitrate concentration increases with the increase in the SPR peak at $441 \mathrm{~nm}$, which confirms that silver nanoparticles have formed. The optimum concentration in this study used $1 \mathrm{mM}$ silver nitrate precursor.

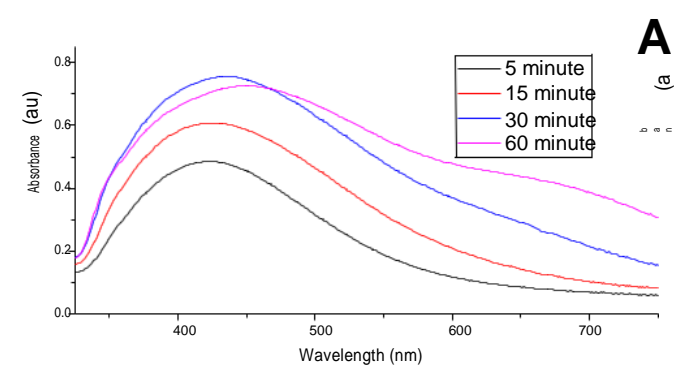

A
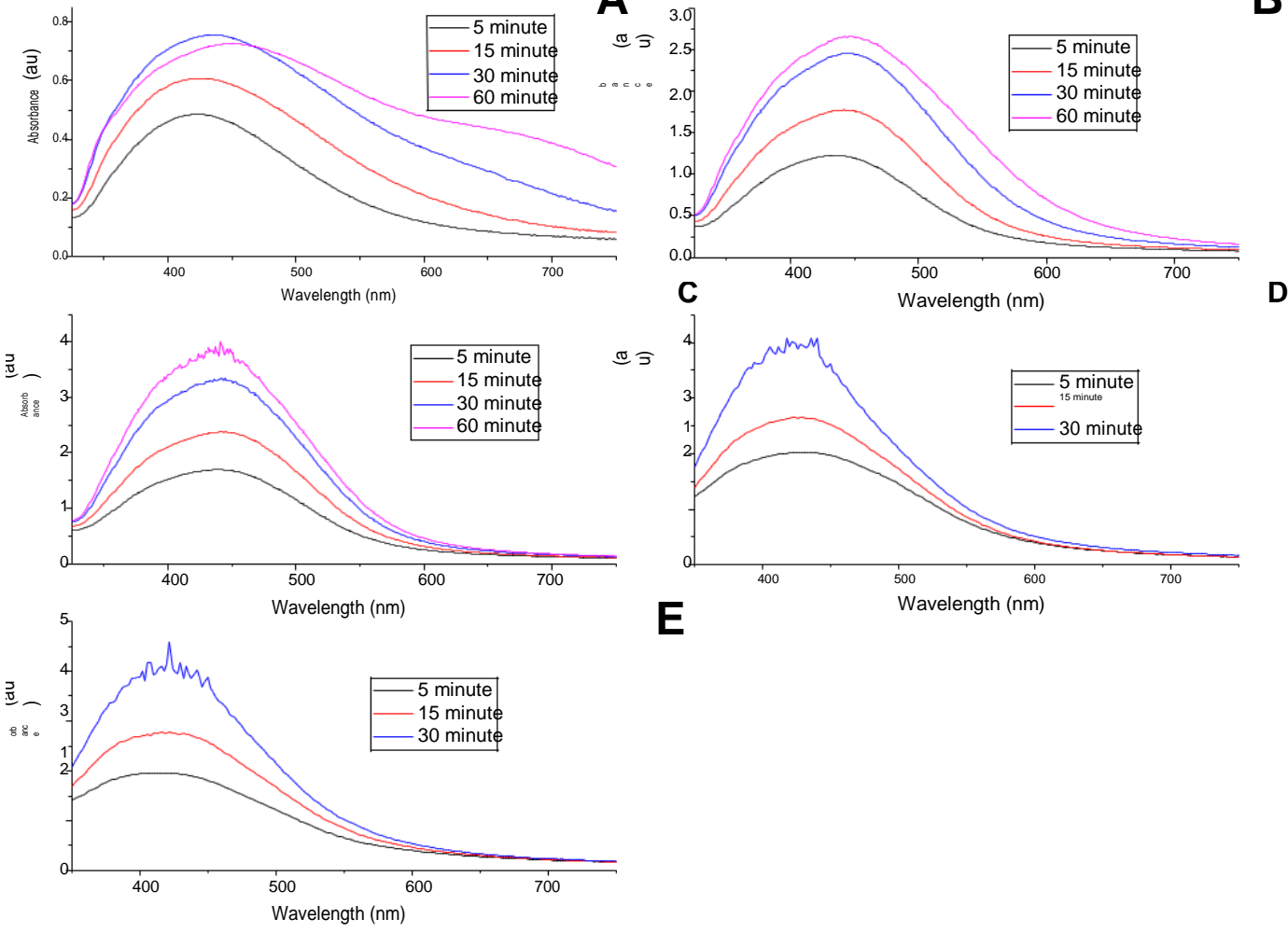

E

Figure 3. A uv-Visible spectrum of silver nanoparticle solution synthesized with variations of Java Long Pepper extract and variations in synthesis time. A. $50 \mu \mathrm{L}$; B. $250 \mu \mathrm{L} ;$ C. $500 \mu \mathrm{L} ;$ D. $1000 \mu \mathrm{L}$,; E. $2000 \mu \mathrm{L}$.

From Figure 3, we can see that the increasing volume of the Java Long Pepperleaf extract that we add will produce more silver nanoparticles, as indicated by the increase in the peak absorbance value of the SPR. This is because the increasing volume of the extract used will create more active sites that can reduce agent for $\mathrm{Ag}^{+}$to $\mathrm{Ag}^{\circ}$ (silver nanoparticles) (Kumar Sur et al., 2018). The absorbance value increased from the volume of the Java Long Pepper leaf extract from $50 \mu \mathrm{L}$ to $2000 \mu \mathrm{L}$. In the extract volumes of 1000 and $2000 \mu \mathrm{L}$, the graph shows irregular peaks; this is probably due to the concentration of silver nanoparticles contained in the solution.

From Figure 3, we can also see that the time of synthesis is very influential on the formation of silver nanoparticles. From the 5th minute, silver nanoparticles have begun to form and increase with increasing synthesis time, as indicated by the increasing peak of the SPR that appears. These results prove that synthesis with the help of sunlight will accelerate the formation of silver nanoparticles; when compared to previous studies, it takes seven days for silver nanoparticles to be synthesized at room temperature (Lutfi et al., 2018). 


\subsection{Characterization of Silver Nanoparticles and Java Long Pepper Leaf Extract 3.2.1 Charaterization using FTIR}

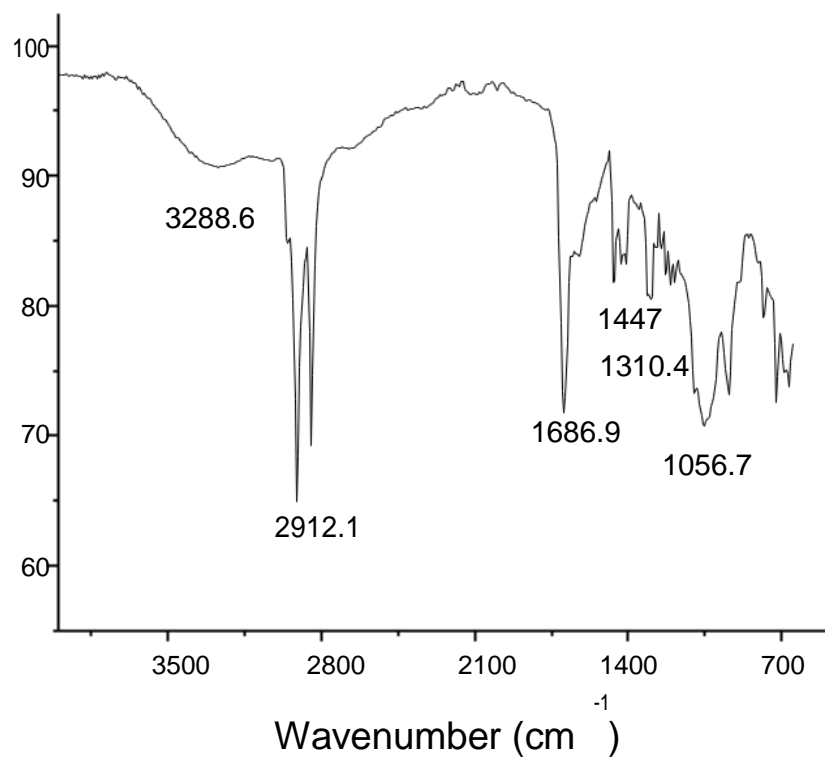

Figure 4. FTIR vibration spectrum of Java Long Pepper leaves

The typical vibration of functional groups found in Java Long Pepperleaves can be seen in the FTIR spectrum. Figure 4. Shown at the wave number $3288.6 \mathrm{~cm}-1$ are vibrations of the hydroxyl $(\mathrm{OH})$ functional group, vibrations of the functional group $\mathrm{C}=\mathrm{O}$ symmetry and asymmetry appear sequentially. At a wavelength of 1447 and $1686.9 \mathrm{~cm}-1$, and at $1057.7 \mathrm{~cm}-1$, it is a vibration of the C-OH functional group. These functional group vibrations that appear confirm what functional groups act as reducing agents contained in the Javan chili leaf extract. More closely at the phenol structure, alkaloids and flavonoids contain hydroxyl and carboxyl groups which can act as reducing agents for silver nitrate to silver nanoparticles $\left(\mathrm{Ag}^{\mathrm{O}}\right)$ where these groups are oxidized (Lutfi et al., 2018; Mat Yusuf et al., 2020; Mohamad et al., 2014). Plant extracts are an excellent choice to become a reducing agent in the green process of synthesizing nanoparticles because the procedure is easy, cheap, efficient, and very possible to manufacture (Hanan et al., 2018).

\subsubsection{Charaterization using TEM}

Silver nanoparticles can be confirmed to have formed; apart from seeing the color change from clear to brownish red due to the reduction of $\mathrm{Ag}^{+}$to $\mathrm{Ag}^{0}$ when measured using the $\mathrm{Uv}-\mathrm{Vis}$ spectrophotometer, the SPR peak will appear. Silver nanoparticles that have formed can also be confirmed from TEM images. From the TEM image in Figure 5, we can see that the synthesized silver nanoparticles are spherical with an average particle diameter of $17.65 \mathrm{~nm}$. The nanoparticles' size varies considerably with the spread of their small size around the larger nanoparticles, indicating the possibility of aggregates forming. At the nanoscale size, the material has different chemical and physical properties from materials of the same composition, which are considerable. This makes nanoparticles such as silver nanoparticles applicable in many fields. This research is applied in its potential to detect $\mathrm{Hg}$ (II) metal ions. 


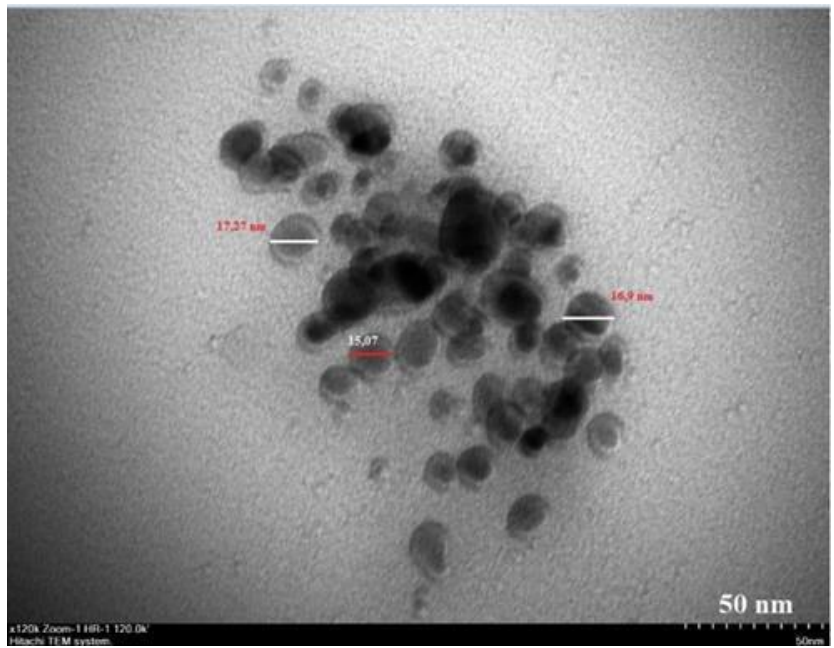

Figure 5. TEM image of silver nanoparticles

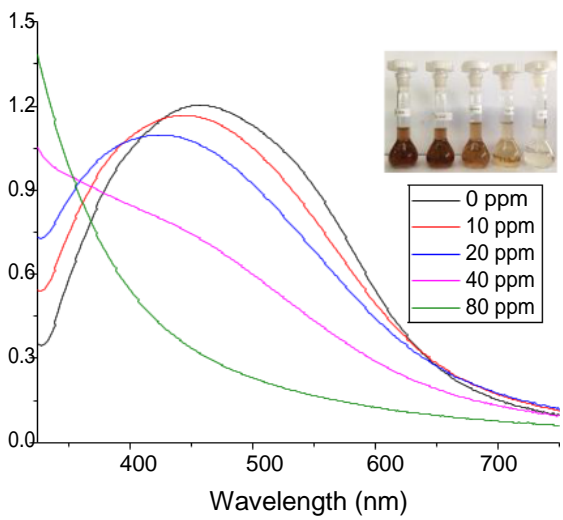

Figure 6. The effect of the addition of $\mathrm{Hg}$ (II) ions on the absorbance value of the SPR silver nanoparticles

Figure 6 shows that the SPR peak of silver nanoparticles has decreased as the concentration of $\mathrm{Hg}$ (II) ions is added. This decrease can be observed directly by changing the color of the silver nanoparticles from brownish red to clear slowly. This is due to the oxidation of $\mathrm{Ag}^{\mathrm{o}}$ to $\mathrm{Ag}^{+}$by $\mathrm{Hg}$ (II) ions as an oxidizing agent. This redox reaction can occur spontaneously based on the standard reduction potential value data $\left(\mathrm{E}^{0}\right)$, resulting in a negative $\Delta$ Go value. With the following redox reactions:

\begin{tabular}{cc}
$2 \mathrm{Hg}^{2+}+2 \mathrm{e}^{-} \rightarrow \mathrm{Hg}_{2}{ }^{2+}$ & $\mathrm{E}^{\mathrm{O}}=+0.92 \mathrm{~V}$ \\
$\mathrm{Ag}^{+}+\mathrm{e}^{-} \rightarrow \mathrm{Ag}$ & $\mathrm{E}^{\mathrm{O}}=+0.8 \mathrm{o} \mathrm{V}$ \\
Reduksi: $2 \mathrm{Hg}^{2+}+2 \mathrm{e} \rightarrow \mathrm{Hg}_{2}{ }^{2+}$ & $\mathrm{E}^{\mathrm{O}}=+0.92 \mathrm{~V}$ \\
Oksidasi: $2 \mathrm{Ag} \rightarrow 2 \mathrm{Ag}^{+}+2 \mathrm{e}^{-}$ & $\mathrm{E}^{\mathrm{O}}=-0.8 \mathrm{o} \mathrm{V} \mathrm{X2}$ \\
\hline $2 \mathrm{Hg}^{2+}+2 \mathrm{Ag} \longrightarrow \mathrm{Hg}_{2}{ }^{2+}+2 \mathrm{Ag}^{+}$ & $\mathrm{E}^{\mathrm{O}}$ sel $=+0,12 \mathrm{~V}$
\end{tabular}




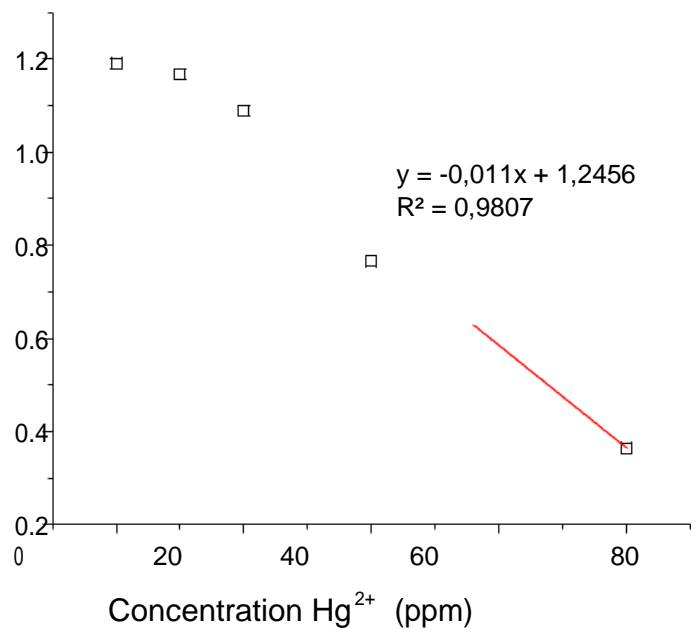

Figure 7. Calibration curve in mercury determination using silver nanoparticles

The relationship between $\mathrm{Hg}$ (II) ions can be plotted into the calibration curve shown in Figure 7. The calibration curve obtained has a correlation coefficient value of 0.9807 . This shows that the increase in the concentration of $\mathrm{Hg}$ (II) ion in the silver nanoparticle solution is proportional to the decrease in the absorbance of the SPR. This calibration curve can be used as a colorimetric method for determining $\mathrm{Hg}$ (II) ions in solution. This is very useful as an alternative method in determining the levels of $\mathrm{Hg}$ (II) ions in solution. Mercury is heavy metal toxic to the human body (Putranto, 2011). Based on the WHO rules in the Guidelines for Drinking-water Quality, the safe limit for mercury ions in drinking water is not more than 0.001 ppm (Kumar and Puri, 2012).

\section{Conclusion}

Green Synthesis of silver nanoparticles using a reducing agent of Java Long Pepper Leaf extract can complement previous studies related to the green synthesis of silver nanoparticles using plant extracts. The optimum silver nanoparticles were synthesized at a precursor concentration of $1 \mathrm{mM}$ silver nitrate for 30 minutes under solar radiation. The change in color of the silver nitrate solution from clear to brownish red confirms the formation of silver nanoparticles, indicating that there has been a reduction of $\mathrm{Ag}^{+}$to $\mathrm{Ag}^{\mathrm{o}}$. The Uv-vis spectrum shows the presence of an SPR peak at $441 \mathrm{~nm}$. From the FTIR spectrum, it can be seen that the vibrations of the distinctive functional groups in the Java Long PepperLeaf extract confirm that the phenolic compounds, alkaloids, and flavonoids present in the extract act as reducing agents. TEM image shows spherical silver nanoparticles with an average diameter of $17.65 \mathrm{~nm}$. The potential of silver nanoparticles to detect $\mathrm{Hg}$ (II) metal is evidenced by a decrease in the color intensity of the silver nanoparticle solution along with the increase in the concentration of $\mathrm{Hg}(\mathrm{II})$, which reverse oxidizes $\mathrm{Ag}^{\mathrm{o}}$ to $\mathrm{Ag}^{+}$.

\section{Acknowledgment}

The author would like to thank the Directorate of Research and Community Service, Directorate General of Research and Development of the Ministry of Research, Technology and Higher Education for providing funding for this research through the SIMLIBTABMAS beginner lecturer research scheme (PDP) 2020 with contract no oog / SP2H / LT / DRPM / 2020. 


\section{References}

Bulska, E., Kandler, W., Pasławski, P., Hulanicki, A., 1995. Atomic Absorption Spectrometric Determination of Mercury in Soil Standard Reference Material Following Microwave Sample Pretreatment. Microchimica Acta, 119: 137-146.

Cava-Montesinos, P., Ródenas-Torralba, E., Morales-Rubio, Á., Cervera, M.L., De La Guardia, M., 2004. Cold Vapour Atomic Fluorescence Determination of Mercury in Milk by Slurry Sampling using Multicommutation. Analytica Chimica Acta, 506: 145-153.

Hanan, N.A., Chiu, H.I., Ramachandran, M.R., Tung, W.H., Mohamad Zain, N.N., Yahaya, N., Lim, V., 2018. Cytotoxicity of Plant-mediated Synthesis of Metallic Nanoparticles: A systematic review. International Journal Molecular Science. 19 (6) : 1725

Ho Lee, G., Kang, G.-J., Kim, J.Y., Russo, R.E., Lee, M.Y., Yang, J.Y., Su Kim, K., Choi, S.H., Yoo, J.H., Mi Choi, E., Yang, J.-S., Su Park, K., 2019. Heavy Metal Determination by Inductively Coupled Plasma

- mass Spectrometry (ICP-MS) and Direct Mercury Analysis (DMA) and Arsenic Mapping by Femtosecond (fs) - Laser Ablation (LA) ICP-MS in Cereals. Analytic Letter, 52: 1-13.

Iyer, R.I., Panda, T., 2018. Biosynthesis of Gold and Silver Nanoparticles Using Extracts of Callus Cultures of Pumpkin ( Cucurbita maxima ) . Journal of Nanoscience and Nanotechnology, 18:53415353.

Khusnia, A.Z., Astorina, N., Rahardjo, M., 2019. Indeks Pencemaran Lingkungan Secara Fisika-Kimia dan Biokonsentrasi Timbal $(\mathrm{Pb})$ pada Kerang Hijau di Perairan Pesisir Semarang Utara. Jurnal Presipitasi Media Komununikasi dan Pengembangan Teknik Lingkungan, 16(2):83-9o.

Kumar, M., Puri, A., 2012. A Review of Permissible Limits of Drinking Water. Indian Jounal Occupational and Environmental Medicine. 16(1):40-44.

Kumar Sur, U., Ankamwar, B., Karmakar, S., Halder, A., Das, P., 2018. Green synthesis of silver nanoparticles using the plant extract of Shikakai and Reetha. Material Today : Proceeding. 5(1): 2321-2329.

Lutfi, F.M., Juwita, M., Ibrahim, P.R., Rakhmawaty, E.D., Iman, R., 2018. Biosynthesis of Silver Nanoparticles using Jicama Extract and Its Application for Colorimetric Sensing of Mercury Ions. Research Journal Chemistry and Environment. 22: 1-3.

Maiti, S., Barman, G., Konar Laha, J., 2016. Detection of heavy metals $\left(\mathrm{Cu}^{+2}, \mathrm{Hg}^{+2}\right)$ by biosynthesized silver nanoparticles. Applied Nanoscience. 6: 529-538.

Mat Yusuf, S.N.A., Che Mood, C.N.A., Ahmad, N.H., Sandai, D., Lee, C.K., Lim, V., 202o. Optimization of biogenic synthesis of silver nanoparticles from flavonoid-rich Clinacanthus nutans leaf and stem aqueous extracts: Biogenic Synthesis of C. nutans AgNPs. R. Soc. Open Science. 7.

Mohamad, N.A.N., Arham, N.A., Jai, J., Hadi, A., 2014. Plant extract as reducing agent in synthesis of metallic nanoparticles: A review. Advance Material Research. 832:350-355.

Mujahid, R., Santoso, S., Fitriana, F., 2018. Pengaruh Jenis Media Terhadap Kandungan Piperin Kalus Daun Cabe Jawa (Piper retrofractum Vahl.) The effect of culture media on piperine content of Cabe jawa (Piper retrofractum Vahl.) leaves callus. Jurnal Tumbuhan Obat Indonesia, 3: 42-46.

Nakano, M., Fujiwara, T., Koga, N., 2016. Thermal Decomposition of Silver Acetate: PhysicoGeometrical Kinetic Features and Formation of Silver Nanoparticles. Jornal Physical Chemistry C 120(16):8841-8854.

Parveen, M., Ahmad, F., Malla, A.M., Azaz, S., 2016. Microwave-assisted green synthesis of silver nanoparticles from Fraxinus excelsior leaf extract and its antioxidant assay. Applied Nanoscience. 6(2)267-276.

Phongtongpasuk, S., Poadang, S., Yongvanich, N., 2016. Environmental-friendly Method for Synthesis of Silver Nanoparticles from Dragon Fruit Peel Extract and their Antibacterial Activities. Energy Procedia,89:239-247.

Putranto, T.T., 2011. Pencemaran Logam Berat Merkuri (Hg) pada Air Tanah. Jurnal Ilmiah Bidang Ilmu Kerekayasaan,32(1):62-71.

Rafique, M., Sadaf, I., Rafique, M.S., Tahir, M.B., 2017. A review on green synthesis of silver nanoparticles and their applications. Artificial Cells. Cells, Nanomedicine, and Biotechnololgy. 45, (7): 1272-1291.

Shahriari, B., Hassanpoor, A., Navehebrahim, A., Jafarinia, S., 2019. A Systematic Review of Green Human Resource Management A systematic review of Green Human Resource Management. Evergreen,6:177-189. 
Shanmugavadivu, M., Kuppusamy, S., Ranjithkumar, R., 2014. Synthesis of Pomegranate Peel Extract Mediated Silver Nanoparticles and its Antibacterial Activity. Jornal of Advanced Drug Delivery, 2: 174-182.

Starowicz, M., Stypuła, B., Banaś, J., 20o6. Electrochemical synthesis of silver nanoparticles. Electrochemistry Communications, 8(2):227-230. 